\title{
The rediscovery of Stenogeocoris horvathi Montandon (Heteroptera, Geocoridae) in Argentina
}

\author{
Pablo M. Dellapé1,4,Gimena Dellapé1,2,4 \& Fernando Martínez 3 ,4
}

\author{
1.División Entomología, Museo de la Plata, UNLP, Paseo del Bosque s/n (B1900FWA), La Plata, Buenos Aires, Argentina. (pdellape@fenym.unlp.edu.ar) \\ 2. Instituto de Diversidad y Evolución Austral (CONICET), Blvd. Brown 2915 (U9120ACD), Puerto Madryn, Chubut, Argentina. \\ (gimenadellape@gmail.com, fjmartinez@cenpat.edu.ar) \\ 3. Instituto Patagónico Para el Estudio de los Ecosistemas Continentales (CONICET) \\ 4.Consejo Nacional de Investigaciones Científicas y Técnicas (CONICET)
}

\begin{abstract}
Stenogeocoris Montandon, 1913 was described to include S. horvathi based in one specimen from Córdoba Province, Argentina. The type specimen is lost and there are no records or additional material since the Montandon's description; thus, the identity of this taxon has remained uncertain until now. In this contribution, we redescribe the genus Stenogeocoris and the species S. horvathi, based on male and female specimens, including characters from the male genitalia, and compare Stenogeocoris with the other Neotropical genera.
\end{abstract}

KEYWORDS. Lygaeoidea, Geocorinae, redescription, Chubut Province.

RESUMEN. EI redescubrimiento de Stenogeocoris horvathi Montandon (Heteroptera, Geocoridae) en Argentina. Stenogeocoris Montandon, 1913 fue descripto para incluir a S. horvathi basado en un espécimen de Córdoba, Argentina. El ejemplar tipo está perdido y no hay registros o material adicional desde la descripción de Montandon. Por lo tanto, la identidad de este taxón ha permanecido incierta hasta ahora. En esta contribución, se redescribe el género Stenogeocoris y la especie $S$. horvathi, basado en especímenes macho y hembra e incluyendo caracteres de la genitalia del macho. Además se compara Stenogeocoris con los otros géneros neotropicales.

PALABRAS CLAVE. Lygaeoidea, Geocorinae, redescripción, Provincia del Chubut.

The Geocoridae, or big-eyed bugs, are a worldwide group comprising 27 genera and about 280 species (HENRY, 2009, 2013; Malipatil, 2012; Rengifo-Correa et al., 2013; Henry et al., in press). The Geocorinae, one of the five subfamilies in which the Geocoridae are separated, occur in all zoogeographic regions, and the Neotropical geocorines are represented by four genera: Isthmocoris McAtee, 1914, Ninyas Distant, 1882, Geocoris Fallén, 1814, and the monotypic Stenogeocoris Montandon, 1913 (Henry et al., in press).

The species Stenogeocoris horvathi was described by Montandon (1913) based on one specimen from Córdoba Province, Argentina. The type specimen is lost and there are no records or references to additional specimens since Montandon's description, thus the identity of the taxon remained uncertain until now (Dellapé, 2014).

In this contribution, we redescribe $S$. horvathi and compare Stenogeocoris with the other Geocorinae Neotropical genera. Photographs of collecting areas, the adult male and female, and illustrations of the male genitalia are included.

\section{MATERIALS AND METHODS}

The specimens were sampled using pitfall traps consisted of open plastic containers, with a capacity of 1000 $\mathrm{ml}$ and $12 \mathrm{~cm}$ of diameter and filled with $300 \mathrm{ml}$ of $30 \%$ ethylene glycol. Trap contents were collected after 15 days and fixed in 70\% ethyl alcohol (Cheli \& CORLEY, 2010).

Color images were captured using a digital camera (Micrometrics 391CU, $3.2 \mathrm{~m}$ ) mounted on a Nikon
SMZ1000 stereomicroscope. Multiple focal planes were merged using Micrometrics SE Premium 4 software. The genital structures were dissected under a stereomicroscope, cleared in a $10 \% \mathrm{KOH}$ aqueous solution, washed in distilled water, and preserved in vials with glycerin. All measurements are in millimeters.

The following acronyms are used for specimen depositories cited in this paper: MLP (Museo de La Plata, Buenos Aires, Argentina) and CNP-CE (Entomological Collection, Instituto Patagónico Para el Estudio de los Ecosistemas Continentales, Puerto Madryn, Chubut, Argentina).

\section{RESULTS}

\section{Stenogeocoris Montandon, 1913}

Type species: Stenogeocoris horvathi Montandon, 1913, by monotypy.

Redescription. Body elongate; shagreened; head coriaceous; pronotum, scutellum and hemelytra coarsely punctuate. Eyes not strongly stylate but large and reniform, about one-quarter of length overlapping pronotum. Ocular suture absent. Ocellus closer to inner margin of eyes than medial line on vertex. Clypeus with a complete median sulcus. Transverse arcuate groove on base of clypeus absent. Rostral segment II shorter than III. Pronotum subquadrangular, without a differentiated collar; pronotal lateral margins weakly carinated. Hemelytra staphylinoid, with clavus and corium fused and indistinguishable. 
Abdominal sterna I to III not fused.

Discussion. Stenogeocoris seems to be related to Geocoris, a large and worldwide genus, with about 127 species (BARANOWSKI \& SLATER, 2005), that appears to be a composite of several genera or subgenera (READIO \& SWeET, 1982; BARANOWSKi \& Slater, 2005).

Stenogeocoris shares with Geocoris the presence of a complete median sulcus on clypeus; the rostral segment II shorter than III, the absence of claval commissure, the basal three abdominal sterna not fused, and with many of the species actually included in the genus the semistylate eyes, overlapping and in contact with the anterior angles of pronotum. The elongate body, about three times longer than wide, and the subquadrangular pronotum, wider at the level of and slightly constricted behind the calli allows separation of Stenogeocoris from Geocoris.

When establishing Stenogeocoris, MonTandon (1913) compared the genus with Stenophthalmicus (Costa, 1875), an Old World genus of elongate, depressed species, having a less expanded scutellum, but pointed out that the shorter body and more cylindrical pronotum distinguished Stenogeocoris.

The strongly stylate eyes and a rostrum with segment II longer than III in Isthmocoris, and the clypeus with only a weak sulcus, the well-developed claval commissure, and the often fused basal three abdominal sterna in Ninyas, will distinguish these two genera from Stenogeocoris. HENRY et al. (in press) presented a key to separate the four Neotropical genera of Geocorinae.

\section{Stenogeocoris horvathi Montandon, 1913}

(Figs 1-13)

Redescription, male. Body elongate (Figs 1-3), about three times longer than wide, total length 3.95. Head: length 0.66 , width 1.31 , with short silvery pilosity; interocular space 0.69; ocelli small, located closer to anterior margin of pronotum than eye; juga reduced and triangular; buccula rounded anteriorly, in dorsal view visible on either side of clypeus, buccular juncture rounded near base of rostrum. Antenna with silvery setae more abundant distally, relatively short, scapus the shortest article, barely surpassing apex of clypeus, distiflagellomere the largest, fusiform, abruptly narrowing at apex; antennal length: scapus 0.22 , pedicellus 0.53 , basiflagellomere 0.41 , distiflagellomere 0.70 . Rostrum extending to mesocoxae (Fig. 2); rostral length: I 0.52, II 0.36, III 0.47, IV 0.34. Pronotum, scutellum and hemelytra glabrous. Pronotum subquadrangular, length 0.76 , maximum width 0.91 , at level of pronotal calli; abruptly narrowing anteriorly and slightly narrowing behind calli; lateral margins weakly carinate; pronotal calli well separated by a central punctured area. Scutellum longer than wide, length 0.66 , width 0.61 ; with a central elevated area prolonged posteriorly into a faint carina. Hemelytra staphylinoid, not reaching posterior margin of tergum III, length 1.07; claval commissure absent, clavus and corium fused and indistinguishable, with raised callouses along claval area and an impunctate posterior fringe. Pleurae (Fig. 3) coarsely punctate; auricle raised and rounded, evaporative area reduced to surrounding areas of auricle. Legs unarmed, pilose, with long setae ventrally on femora, restricted to proximal half on meso and metafemora. Abdomen with sparse, short, silvery setae, longer ventrally; maximum abdominal width 1.41.

Genitalia: pygophore with dorsal aperture as seen in Figs 4-5, declivent posteriorly (Fig. 5). Parameres: blade curved (Figs 6, 8) and strongly angled (Figs 7, 9), shank with inner projection directed basally. Aedeagus (Figs 1012): ejaculatory reservoir with wings directed backward, processus gonopory extremely long with many coils.

Coloration. General coloration black, except the areas as follows: apex of clypeus, juga and a small area before antenniferous tubercles pale brown (forming a fringe from eye to eye), buccula outline whitish. Antenna light brown, tinged with red, distiflagellomere lighter. Rostrum brown. Hemelytra fuscous, with raised calli on claval area and distal fringe whitish. Acetabular areas, auricle, and metaepisternum dorsally whitish. Prosterna light brown. Prosterna and propleura delimiting a lighter collar-like area. Legs: femora brown except apices paler, rest of legs light brown.

Female (Fig. 13): similar to male in all aspects. Abdomen wider. The female collected along Punta Ninfas Road has the whitish areas less evident and reddish tonalities on the antenna and legs.

Measurements (female from Península Valdés and from Punta Ninfas Road respectively): Total length, 4.19-3.99. Head length, 0.78-0.71; width, 1.49-1.44. Intercocular space, 0.88-0.82. Pronotal length, 0.80-0.80; width, 1.10-1.03. Scutellar length, 0.74-0.72; width, 0.730.68 . Hemelytra length, 1.21-1.15. Antennal length: scapus $0.23-0.23$, pedicellus $0.60-0.54$, basiflagellomere 0.48 0.47 , distiflagellomere $0.73-0.74$. Rostral lenght: I 0.500.54, II 0.40-0.36, III 0.48-0.46, IV 0.37-0.36. Maximum abdominal width 1.57-1.47.

Material examined: ARGENTINA, Chubut: Península Valdés (Res. San Pablo, 42 ${ }^{\circ} 41^{\prime} 57.94$ 'S, 64¹1'58.14”W, 83 m asl), Ò, 11.II.2010, F. Martínez col. (MLP); Península Valdés (Res. San Pablo, 42³7’48.25”S, $64^{\circ} 10^{\prime} 18.25^{\prime} \mathrm{W}, 70 \mathrm{~m}$ asl), + , 11.II.2010, F. Martínez col. (MLP); Puerto Madryn (Camino a Punta Ninfas, 42 50’09.73”S, 6501'19.80”'W, 124 m asl), +, 26.III.2011, N. Martínez Román col. (CNP-CE).

Remarks. According to SLATER (1975) classification on wing development in lygaeids (sensu lato), the short forewings of $S$. horvathi, not reaching the posterior margin of tergum III and with clavus and corium fused, correspond to the staphylinoid type, with the only difference being that the forewings overlap somewhat on the midline more than meeting evenly.

Although there are several species with some degree of brachyptery in the Geocoridae, the modified staphylinoid forewings of $S$. horvathi are unusual within the family. SLATER (1977) stated that this type of wing reduction is present in geophile or ground-inhabiting lygaeoids, a likely habitat for $S$. horvathi as suggested by our three specimens 

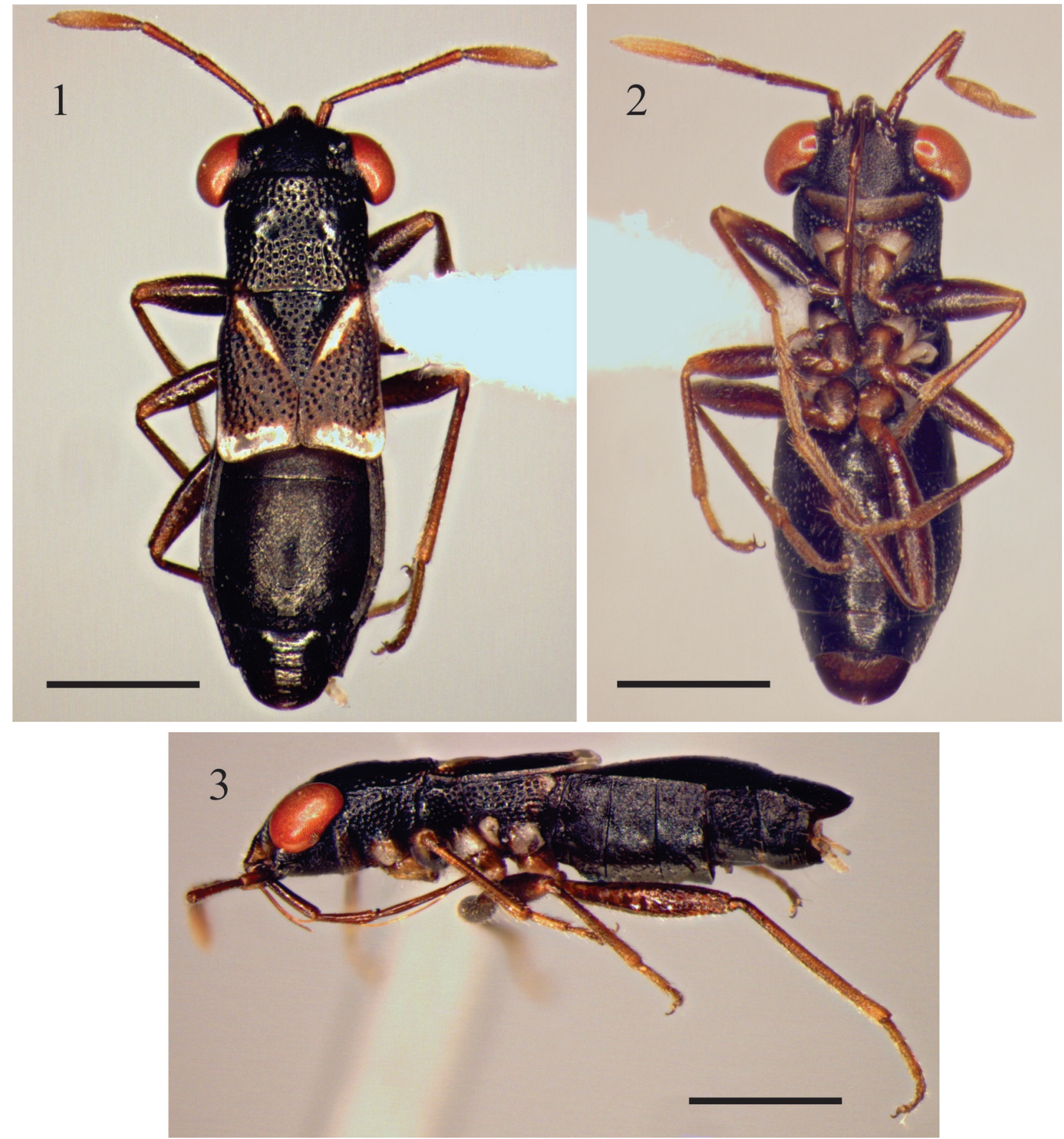

Figs 1-3. Stenogeocoris horvathi Montandon, male. 1, dorsal view; 2, ventral view; 3, lateral view. Scale bars $=1 \mathrm{~mm}$.

collected in pitfall traps. Presumably, it is a predator as are other members of the subfamily (SCHUH \& SLATER, 1995).

Collecting sites. All specimens were collected in northeastern Chubut Province, Argentina (Figs 14, 15). The annual mean temperature is $13.7^{\circ} \mathrm{C}$ and the average annual precipitation is $188 \mathrm{~mm}$, with a high mean interannual variation (Dellapé \& CHELI, 2007).

Two specimens were collected in the Reserva de Vida Silvestre San Pablo de Valdés, located in southwestern Península Valdés. One female was collected in a shrub steppe (Fig. 16) dominated by Chuquiraga avellanedae Lorentz (Asteraceae), Lycium chilense Miers ex Bert.
(Solanaceae), Schinus johnstonii Barkley (Anacardiaceae) and Menodora robusta (Benth.) A. Gray (Oleaceae). The plant canopy has a random patchy structure formed by clumps of shrubs and perennial grasses [Nasella tenuis (Phil.) Barkworth and Poa ligularis Nees ex Steud (Poaceae)] on a matrix of bare soil or sparse vegetation (BURGI et al., 2012). The male specimen was collected in a dwarf-shrub steppe (Fig. 17) dominated by Hyalis argentea D.Don ex Hook. \& Arn. (Asteraceae), with isolated shrubs of Suaeda divaricata Moq. (Chenopodiaceae), Chuquiraga avellanedae, Lycium chilense, and patches dominated by Cyclolepis genistoides Gillies ex D.Don (Asteraceae) 
or Baccharis divaricata Hauman (Asteraceae) (BurgI et al., 2012). The soil in this vegetation community is composed of sand deposits derived from sandy beaches and transported inland by prevailing westerly winds (DEL VALLE et al., 2008).
An additional female was collected $15 \mathrm{~km}$ southeast of Puerto Madryn city (Punta Ninfas Road). The vegetation is a shrubland of Larrea spp. and Stipa spp. (Fig. 18), characteristic of the southern portion of the Monte Phytogeographic Province (León et al., 1998).
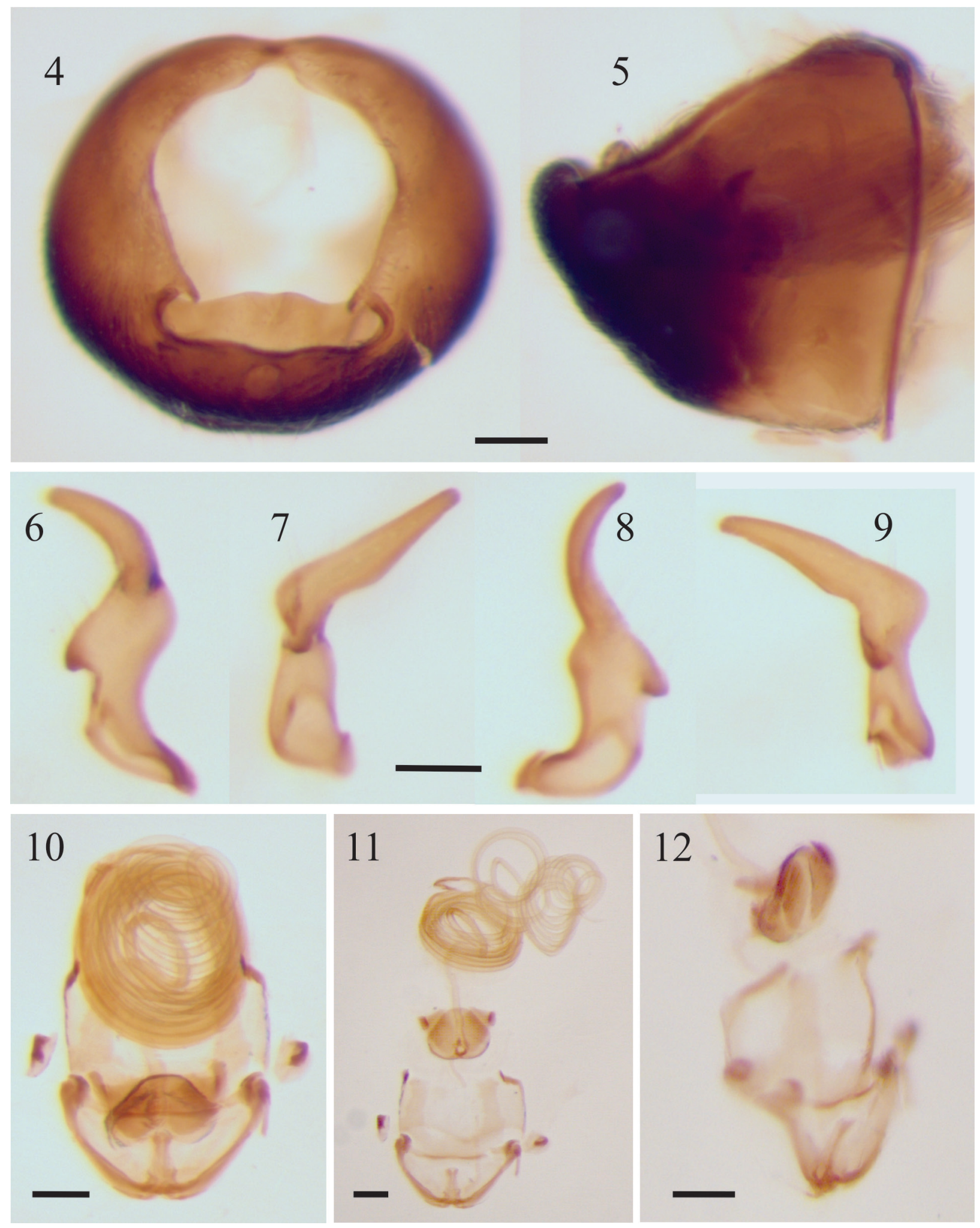

Figs 4-12. Stenogeocoris horvathi Montandon, male genitalia. 4-5, Pygophore: 4, dorsal view; 5, lateral view. 6-9, Right paramere: 6, outer view; 7, lateral view; 8 , inner view; 9, lateral view. 10-12, Aedeagus: 10, 12, anterior view; 11, antero-lateral view. Scale bars $=0.1 \mathrm{~mm}$. 


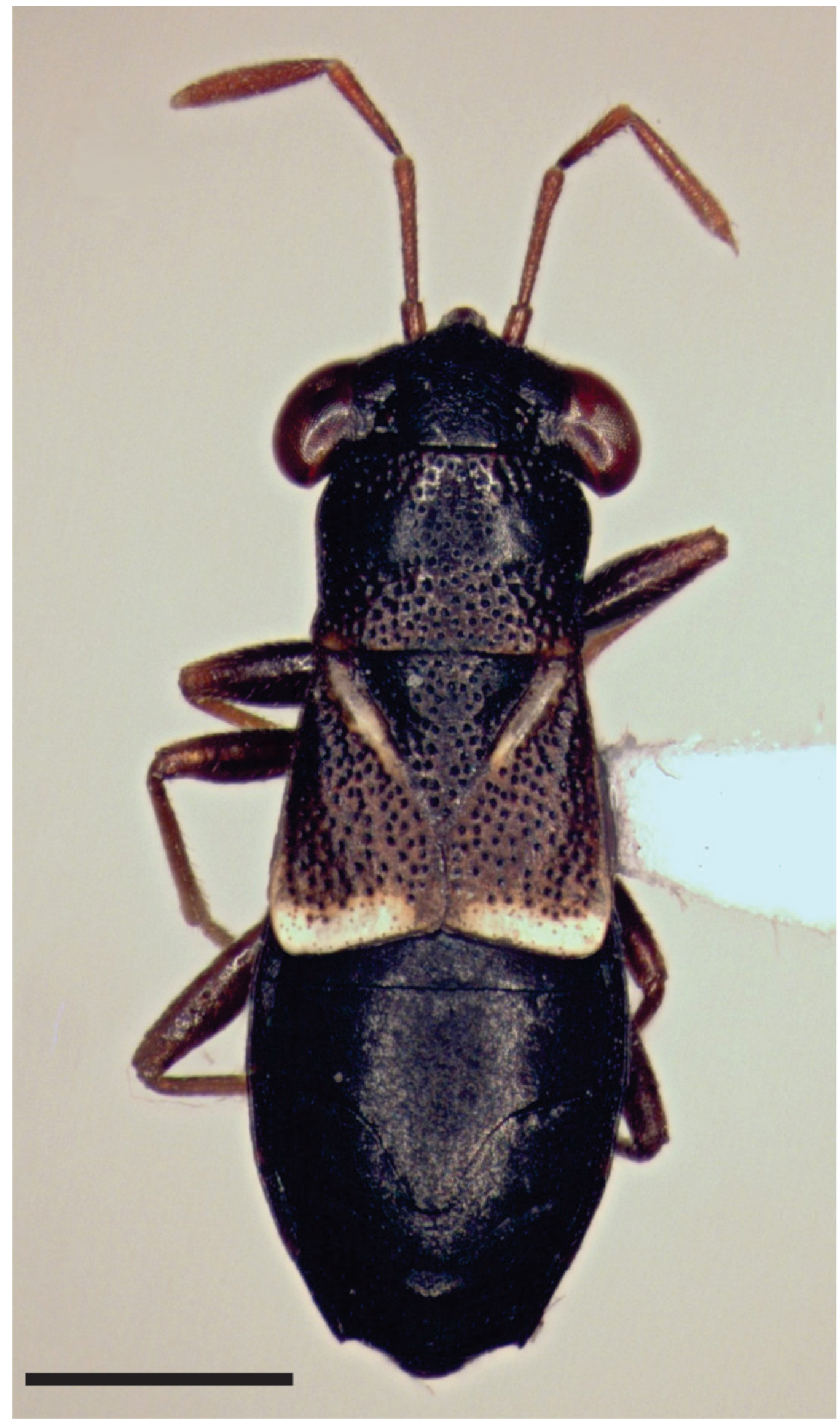

Fig 13. Stenogeocoris horvathi Montandon, female, dorsal view. Scale bars $=1 \mathrm{~mm}$. 

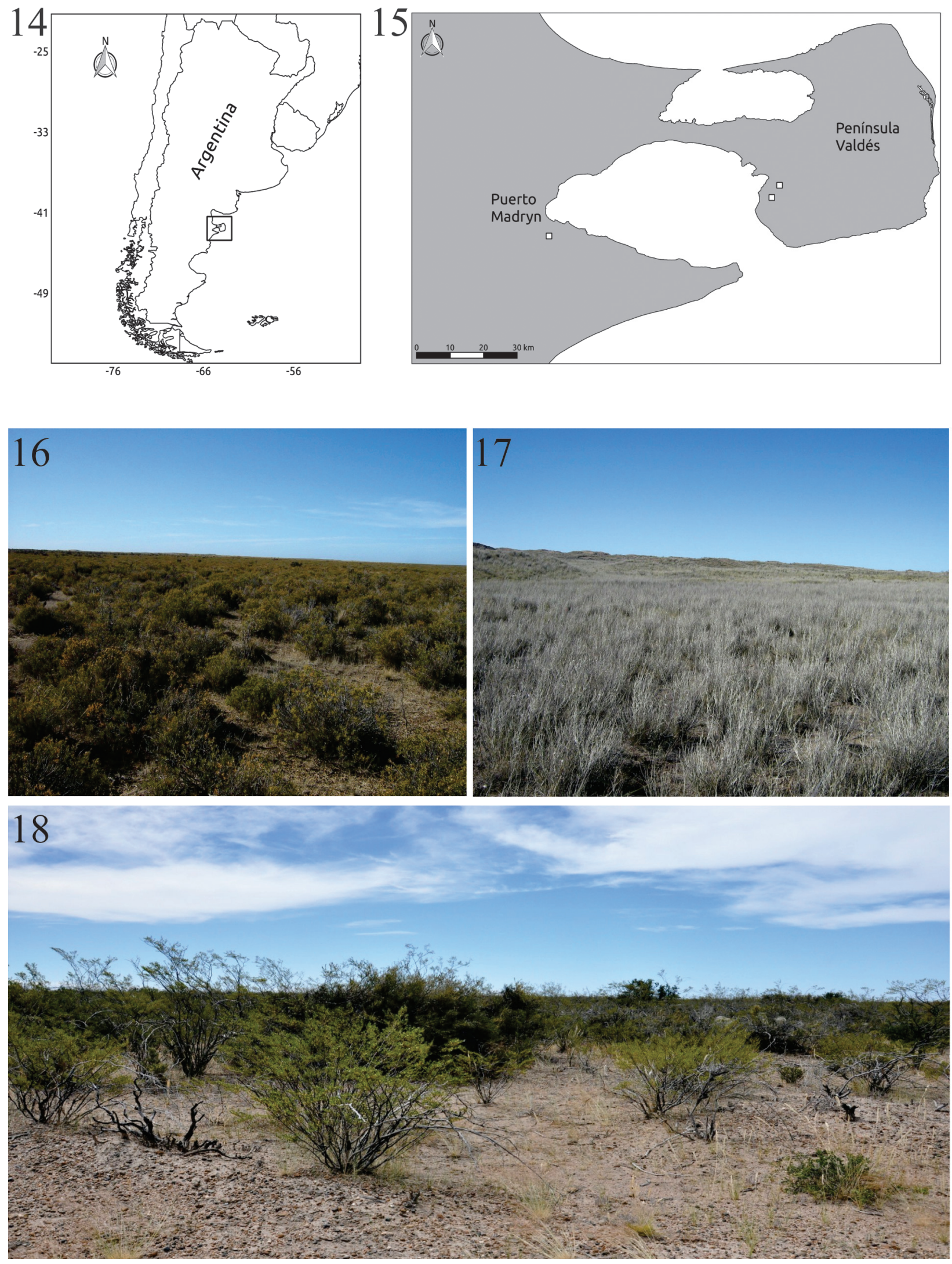

Fig 14-18. Study area. 14-15, Collecting sites (white squares). 16, shrub steppe. 17, dwarf-shrub steppe of Hyalis argentea. 18, vegetation characteristic of the southern portion of the Monte Phytogeographic Province. 
Vegetation covers $40-60 \%$ of the area and has a random patchy structure formed by shrub clumps encircled by grasses, grass patches, and bare soil (BISIGATO \& BERTILLER, 1997). This last area was severely affected by wildfire in 2001 (HARDTKE et al., 2015).

Acknowledgements. We thank to N. Martínez Román and G. H. Cheli for help during the fieldwork and to Reserva de Vida Silvestre San Pablo de Valdés - Fundación Vida Silvestre Argentina for access to the study areas. We thank to Elöd Kondorosy (Pannon University Georgikon Faculty, Hungary) and Mária Tóth-Ronkay (Hungarian Natural History Museum, Hungary) for their help in the search of the Montandon's type of S. horvathi. We also thank Thomas Henry (Systematic Entomology Laboratory [SEL], ARS, USDA, c/o National Museum of Natural History, Washington, DC) for the critical reading of the manuscript.

\section{REFERENCES}

Baranowski, R. M. \& Slater, J. A. 2005. The Lygaeidae of the West Indies. Florida Agricultural Experiment Station Bulletin 402:1266.

Bisigato, A. J. \& Bertiller, M. B. 1997. Grazing effects on patchy dryland vegetation in northern Patagonia. Journal of Arid Environments 36:639-653.

Burgi, M. V.; Marino, A.; Rodríguez, M. V.; Pazos, G. \& Baldi, R. 2012. Response of guanacos Lama guanicoe to changes in land management in Península Valdés, Argentine Patagonia: conservation implications. Oryx 46:99-105.

Cheli, G. H. \& Corley, J. C. 2010. Efficient Sampling of GroundDwelling Arthropods Using Pitfall Traps in Arid Steppes. Neotropical Entomology 39:912-917.

Dellapé, P. M. 2014. Lygaeoidea. In: RoIG-Juñent, S.; Claps, L. E. \& Morrone, J. J. eds. Biodiversidad de Artrópodos Argentinos. San Miguel de Tucumán, INSUE. v. 3, p.421-438.

Dellapé, P. M. \& Cheli, G. H. 2007. A new species of Anomaloptera Amyot \& Serville from Patagonia (Hemiptera: Lygaeoidea: Oxycarenidae). Zootaxa 1528:65-68.

Del Valle, H. F.; Rostagno, C. M.; Coronato, F. R.; Bouza, P. J. \& Blanco, P. D. 2008. Sand dune activity in north-eastern Patagonia. Journal of Arid Environments 72:411-422.

Hardtke, L. A.; Blanco, P. D.; Del Valle, H. F.; Metternicht, G. I. \& SiONE, W. F. 2015. Semi-automated mapping of burned areas in semiarid ecosystems using MODIS time-series imagery. International Journal of Applied Earth Observation and Geoinformation 38:25-35.
Henry, T. J. 2009. Biodiversity of Heteroptera. In: Foottit, R. \& AdLER, P. eds. Insect biodiversity: Science and society. Oxford, Blackwell, p.223-263.

.2013. Cymapamphantus valentineorum, a new genus and species of Pamphantinae (Heteroptera: Lygaeoidea: Geocoridae) from the British Virgin Islands, with a checklist of the species and keys to the tribes and genera of the subfamily. Proceedings of the Entomological Society of Washington 115:392-401.

Henry, T. J.; Dellapé, P. M. \& Silva P. A da. The Big-Eyed Bugs, Chinch Bugs, and Seed Bugs (Lygaeoidea). In: Panizzi, A. \& Grazia, J. eds. True Bugs (Heteroptera) of the Neotropics. London, Springer (in press).

León, J. C. R.; Bran, D.; Collantes, M.; Paruelo, J. M. \& Soriano, A. 1998. Grandes unidades de vegetación de la Patagonia extra andina. Ecología Austral 8:125-144.

MaLIPATIL, M. B. 2012. Australocorinae, a new subfamily of Geocoridae (Hemiptera: Heteroptera, Lygaeoidea) from Australia, with descriptions of a new genus and two new species. Zootaxa 3554:7588.

Montandon, A. L. 1913. Nouvelles formes de Geocorinae appartenant aux collections du Muséum national Hongrois. Annales HistoricoNaturales Musei Nationalis Hungarici 11:211-219.

REAdio, J. \& SweET, M. H. 1982. A review of the Geocorinae of the United States of the $100^{\text {th }}$ Meridian (Hemiptera: Lygaeidae). Miscellaneous Publications of the Entomological Society of America 12:1-91.

Rengifo-Correa, L.; Brailovsky, H.; Henry, T. J. \& Morrone, J. J. 2013. Phylogenetics and evolutionary morphology of the Neotropical true bug genus Epipolops (Hemiptera: Heteroptera: Geocoridae). Systematic Entomology 39:127-140.

Schuh, R. T. \& Slater, J. A. 1995. True Bugs of the World (Hemiptera: Heteroptera): Classification and Natural History. Ithaca and London, Cornell University Press. 337p.

Slater, J. A. 1975. On the biology and zoogeography of Australian Lygaeidae (Hemiptera: Heteroptera) with special reference to the southwest fauna. Journal of the Australian Entomological Society 14:47-64

1977. The incidence and evolutionary significance of wing polymorphism in lygaeid bugs with particular reference to those of South Africa. Biotropica 9:217-229. 